\title{
Lysosomes in Normal Pancreatic Beta Cells
}

\author{
P. Meda \\ Department of Histology, University of Louvain, Faculty of Medicine, Brussels, Belgium
}

\begin{abstract}
Summary. Lysosomes and their relationships with surrounding organelles were studied in pancreatic Bcells of normal Wistar rats by electron microscopy and cytochemical localization of acid phosphatase (AcPase) and arylsulphatase. Several forms of lysosomes were distinguished and shown to interact frequently with the secretory granules. Two different digestive processes were recognized. During crinophagy, lysosomes directly fuse with secretory granules while, during autophagy, a cytoplasmic area containing secretory granules and/or other organelles is circumscribed before the enzymatic digestion. In addition, lysosomes may transport arylsulphatase into secretory granules apparently not involved in a destructive process. Such a process could also account, at least in part, for the presence of AcPase in a certain number of mature and immature secretory granules.
\end{abstract}

Key words: B-cell, lysosomes, autophagy, crinophagy, electron microscopy, acid phosphatase, arylsulphatase.

Interactions of lysosomes with the secretory products have been demonstrated in various endocrine cells $[14,15,19,34,37,39]$ including those of the islets of Langerhans both in pathological $[29,30,32]$ and experimental conditions $[5,8,9,24,29,30]$. However, except for the demonstration of acid phosphatase activity in a population of insulin-containing granules $[1,5,27,33]$, there is no definitive evidence for a role of lysosomes in the secretory cycle of normal islet cells $[20,38]$. We have thus investigated the various forms of lysosomes in resting pancreatic Bcells of normal rats in order to clarify their relation- ships with the surrounding organelles and, in particular, with the secretory granules.

\section{Material and Methods}

Islets of Langerhans were isolated from the pancreas of fed male Wistar rats, weighing $250-300 \mathrm{~g}$, by collagenase digestion [21] (Collagenase Type I, Sigma Chemical Company, St. Louis, Mo). Microdissected islets and small blocks of pancreatic tissue were also analyzed.

For morphological studies, the tissues were fixed for one hour at room temperature in $2 \%(\mathrm{v} / \mathrm{v})$ glutaraldehyde (Taab Laboratories, Reading, England) in $0.1 \mathrm{~mol} / 1$ phosphate buffer, $\mathrm{pH} 7.3$, with $0.05 \mathrm{~g} / 1$ calcium chloride. After being washed in a buffer of the same composition, they were postfixed for one hour in $1 \%(\mathrm{v} / \mathrm{v})$ osmium tetroxide (Merck, Darmstadt, Germany) in Millonig's buffer, $\mathrm{pH}$ 7.3.

For cytochemical studies, the tissues were fixed in $2 \%(\mathrm{v} / \mathrm{v})$ glutaraldehyde in $0.1 \mathrm{~mol} / \mathrm{l}$ cacodylate buffer, $\mathrm{pH} 7.4$, which contained $34 \mathrm{~g} / \mathrm{l}$ sucrose. After one hour fixation, they were embedded in a drop of $70 \mathrm{~g} / \mathrm{l}$ agar and cut at $30 \mu$ with a tissue sectioner [36]. The sections were stored overnight at $4^{\circ} \mathrm{C}$ in cacodylate-sucrose buffer and were subsequently incubated as detailed below.

Detection of acid phosphatase (AcPase) activity was performed according to the method of Gomori [18] as modified by Barka and Anderson [3]. The medium consisted of $40 \mathrm{mmol} / \mathrm{l}$ trismaleate buffer, $\mathrm{pH} 5.0$, containing $70 \mathrm{~g} / 1$ sucrose, $11.6 \mathrm{mmol} / \mathrm{l} \mathrm{Na}-\beta$ glycerophosphate (Sigma Chemical Company, St. Louis, Mo.) and $2.4 \mathrm{mmol} / \mathrm{l}$ lead nitrate. Incubations were performed at $37^{\circ} \mathrm{C}$ for $45 \mathrm{~min}$. Control batches were incubated either in substrate-free medium or in complete medium supplemented with $10 \mathrm{mmol} / 1$ sodium fluoride. 


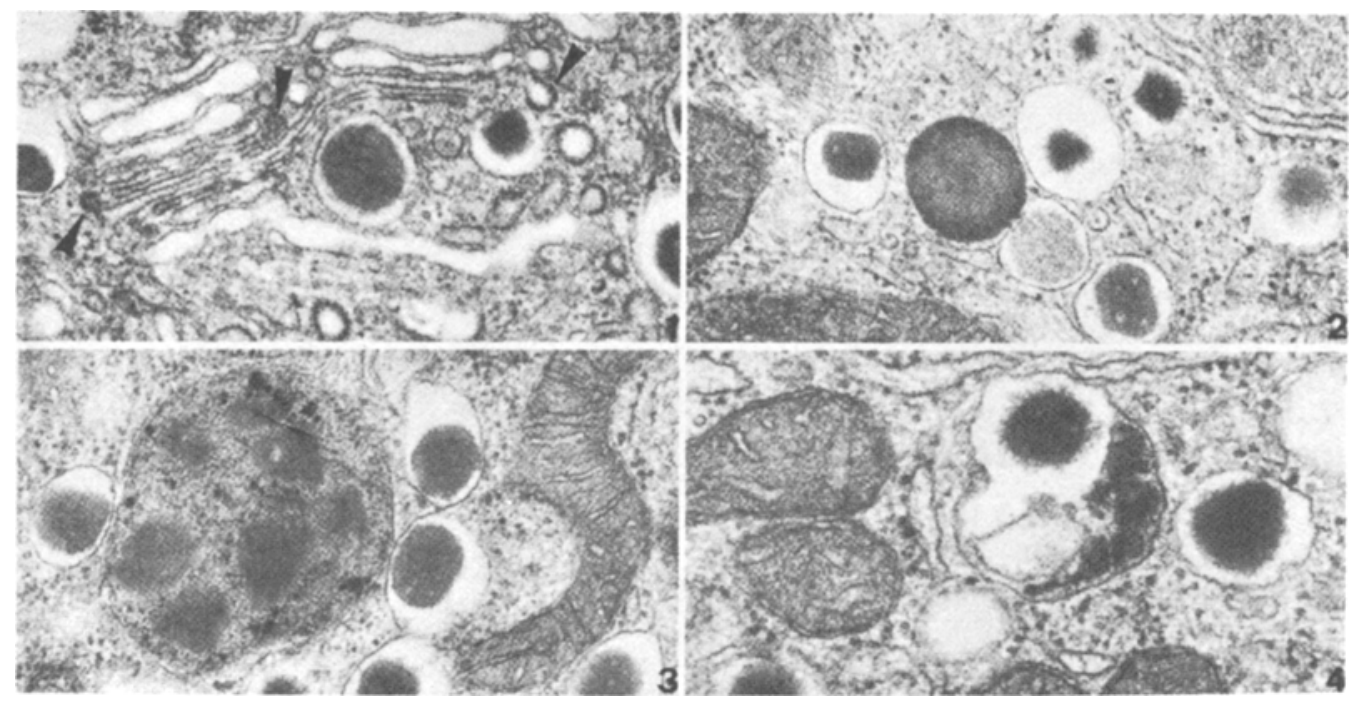

Fig. 1. Golgi region of a resting B-cell showing the stack of cisternae and its associated vesicles. The arrow-heads point to some coated vesicles continuous with the innermost cisternae of the concave face. $\times 34^{\prime} 000$

Fig. 2. Single membrane-limited dense body with homogenous content. Such organelles may represent the morphological counterpart of primary lysosomes. $\times 34^{\prime} 000$

Fig. 3. Typical secondary lysosome containing heterogenous material and clearly recognizable beta granules cores. $\times 34^{\prime} 000$

Fig. 4. A beta granule and the heterogenous material of a lysosome are enclosed within the same membrane. $\times 51^{\prime} 000$

The arylsulphatase (AS) activity was demonstrated according to the method of Goldfischer [17] using a medium composed of $0.1 \mathrm{~mol} / 1$ Veronal acetate buffer, $\mathrm{pH} 5.5$, containing $50 \mathrm{~g} / \mathrm{l}$ sucrose, 18.7 $\mathrm{mmol} / 1 \mathrm{p}$-nitrocatechol sulphate (Sigma Chemical Company, St. Louis, Mo.) and $22.4 \mathrm{mmol} / 1$ lead nitrate. Incubations were performed for $3 \mathrm{~h}$ at $25^{\circ} \mathrm{C}$. Control batches were heated $5 \mathrm{~min}$. at $90^{\circ} \mathrm{C}$ before incubation or incubated in substrate-free medium.

After incubation, the tissues were washed several times in the corresponding buffers and post-fixed for one hour in $1 \%(\mathrm{v} / \mathrm{v})$ osmium tetroxide in $0.1 \mathrm{~mol} / \mathrm{l}$ cacodylate buffer, $\mathrm{pH}$ 7.4. All the tissues were dehydrated in a graded ethanol series and embedded in Epon [23]. Thin sections were cut with a Reichert OM U3 ultramicrotome and examined either without staining (cytochemical studies), or after staining with uranyl acetate and lead nitrate (morphological studies) in an EM 301 Philips electron microscope.

\section{Results}

\section{Conventional Morphology}

In normal pancreatic B-cells, the Golgi complex consists of crescent-like stacks of cisternae that delimit a cytoplasmic region containing numerous coated and smooth-surfaced vesicles in addition to immature and mature secretory granules. Coated vesicles are frequently continuous with one of the two or three innermost cisternae of the concave face (Fig. 1). Several types of lysosomes are seen in B-cells. Some appear roundish and homogeneously dense (Fig. 2), but most of them are characterized by heterogenous contents. Frequently, the contents bear resemblance with beta granule cores (Fig. 3), or with remnants of cytoplasmic matrix and/or organelles. Lysosomes may also take the form of multivesicular bodies, i.e. that of a collection of small vesicles enclosed within a vacuole bounded by a single membrane. Lysosome of all types appear closely associated with secretory granules (Fig. 4) or with autophagic vacuoles (see below).

\section{Cytochemistry}

Acid Phosphatase: AcPase activity is localized within the innermost cisternae at the concave face of the Golgi stacks, while only rare, variable deposits of the reaction product occur in the contiguous cisternae of the convex face (Fig. 5). Moreover, few AcPase positive vesicles are found in the Golgi region, (Fig. 6), as well as dispersed in the cytoplasm. Lysosomes may contain only reaction product (Fig. 7) but most of them show in addition unreactive structures (Figs. 8 


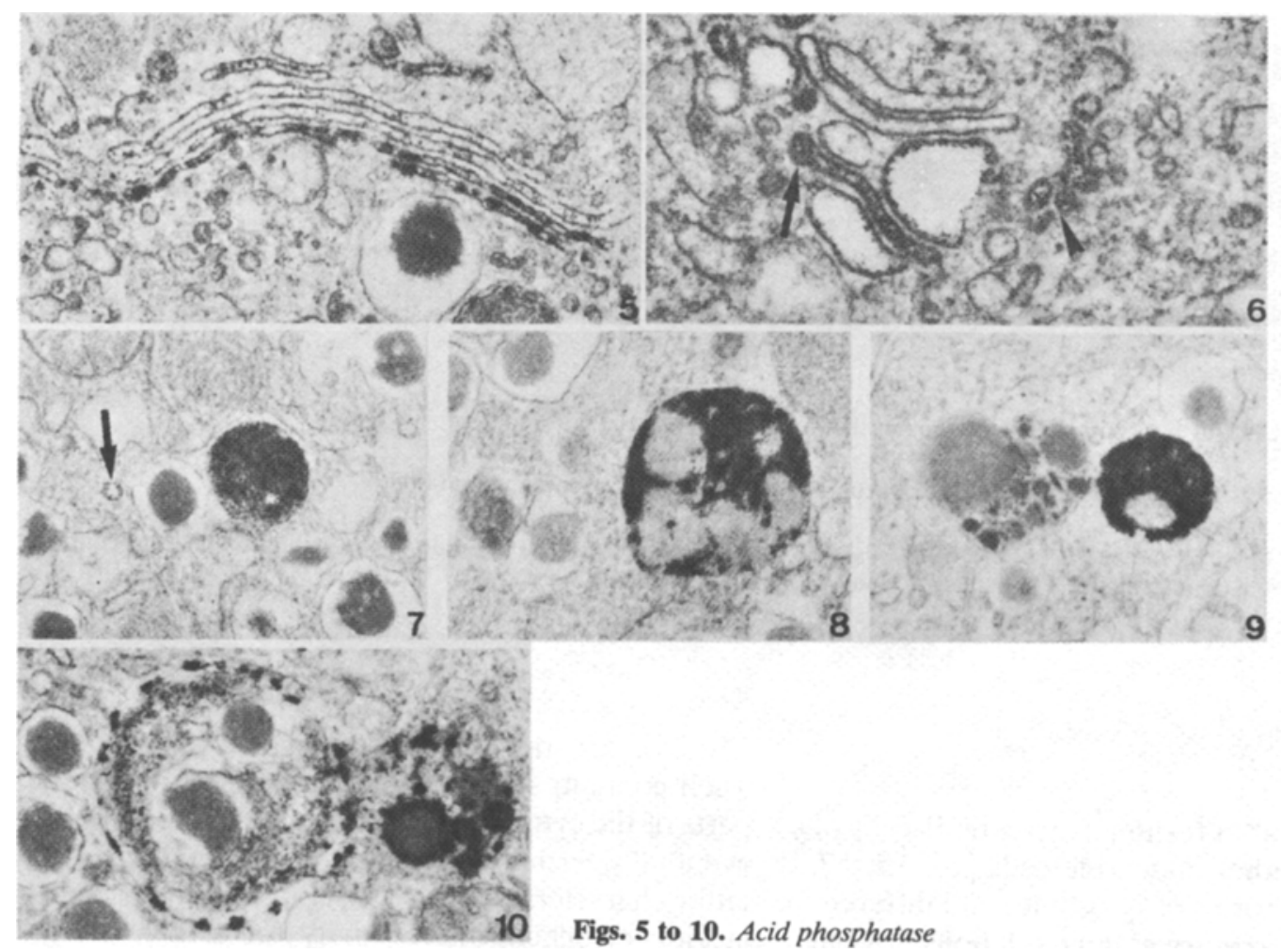

Fig. 5. The reaction product nearly fills the two innermost cisternae at the concave face of this Golgi stack. In contrast, only scarce precipitates are seen within the cisternae of the convex face. $\times 34^{\prime} 000$

Fig. 6. The AcPase activity is detected in both narrow and expanded Golgi cisternae (arrow), as well as within some vesicular profiles (arrow-head). Other Golgi cisternae and associated vesicles appear unreactive. $\times 34^{\prime} 000$

Fig. 7. AcPase activity is demonstrated in a small vesicle (arrow) as well as in a larger dense body. $\times 34^{\prime} 000$
Fig. 8. Typical secondary lysosome containing recognizable secretory granules cores embedded in a matrix heavily stained with reaction product. $\times 34^{\prime} 000$

Fig. 9. Dense body loaded with heterogenous material but without demonstrable AcPase activity. Reaction product is seen in a neighbouring lysosome. $\times 34^{\prime} 000$

Fig. 10. Two beta granules with part of their limiting membrane preserved, are enclosed within an autophagic vacuole. AcPase reaction product underlines the vacuolar membrane and is also found in some areas of the vacuole's content. $\times 34^{\prime} 000$ and 9). Some lysosomes filled with heterogenous material are frequently unreactive (see Fig. 9). AcPase activity is also detected in parts of autophagic vacuoles containing secretory granules and/or cytoplasmic matrix (Fig. 10). As described previously [1], a population of beta granules apparently not involved in a digestive process was also found to contain AcPase concentrated in the halo between the core and the granule limiting membrane.

Arylsulphatase: One main difference between AcPase and AS reactive sites in our material is the absence of AS reactivity in Golgi cisternae and their associated coated vesicles. Another difference is that reactive vesicles of all sizes are more numerous in AS
(Fig. 11) than in AcPase preparations. AS-positive vesicles are often closely associated with autophagic vacuoles (Fig. 12). In addition, AS-containing vesicles may appear close to beta granules and a continuity is sometimes observed between the precipitate in the vesicle and a material of similar texture and density that partly fills the granule halo (Fig. 13).

\section{Control Experiments}

No deposits of the reaction product occurred in thin sections cut from blocks of control batches. Similar morphological and cytochemical data were obtained in all types of islets examined, regardless of the preparative procedure. 


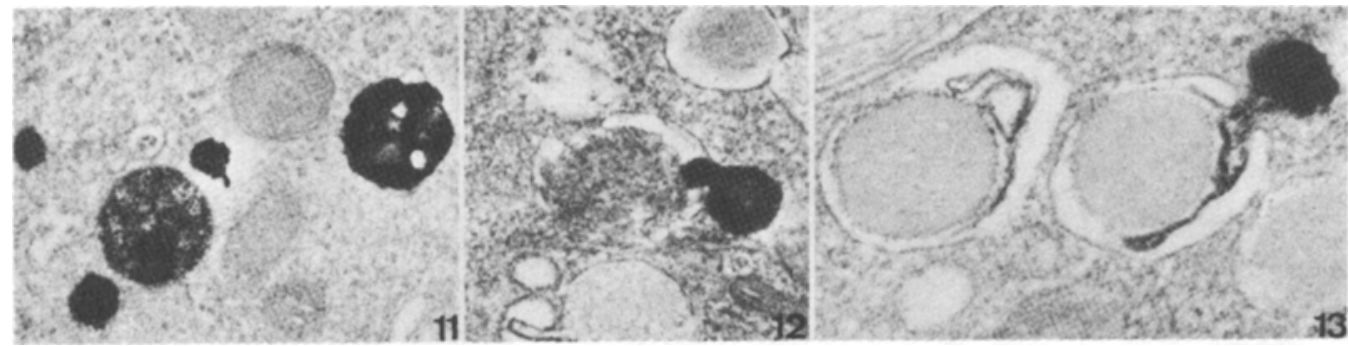

Figs. 11 to 13. Aryl-sulphatase preparations

Fig. 11. As reaction product fills lysosomes of varying sizes, the larger with heterogenous content. $\times 40^{\prime} 000$

Fig. 12. Apparent continuity between a small autophagic vacuole and a reactive lysosome. $\times 40^{\prime} 000$

Fig. 13. Reaction product is present in some parts of the halos of two beta granules. In the granule to the right, an apparent continuity between the deposit in the halo and that in a small dense body is seen. $\times 60^{\prime} 000$

\section{Discussion}

This study shows that in resting pancreatic B-cells of normal rats, as in other endocrine cells $[14,15,19$, $34,37,39)$, several forms of lysosomes and different types of lysosome-secretory granule relationships can be recognized on the basis of their morphological and cytochemical characteristics. Functionally, lysosomes are labelled primary, secondary and tertiary (or residual) depending on the stage of the digestive activity $[10,11,25]$. Primary lysosomes are described as membrane-bounded organelles containing hydrolytic enzymes but not yet engaged in digestion. In the pancreatic B-cell, cytochemical candidates for primary lysosomes are AcPase reactive vesicles closely associated with the concave face of the Golgi stacks [22] as well as coated vesicles opening into the Golgi cisternae $[27,30]$. These findings are confirmed in the present work, which shows that AcPase positive vesicles, both smooth and coated, bud from reactive cisternae of the Golgi stacks. Surprisingly, however, no AS activity is detected in such vesicles which, thus, satisfy only partially the biochemical definition of a lysosome, i.e. an organelle containing several hydrolytic enzymes.

On the contrary, several smooth-surfaced vesicles dispersed in the cytoplasm show AcPase as well as AS reactivity. These organelles appear to be primary lysosomes since they are completely filled with reaction product and do not contain unreactive material. Some of them have a size similar to that of the Golgiassociated vesicles, but others are as large as secondary lysosomes. Secondary lysosomes, i. e. membrane-bounded organelles containing acid hydrolases and material in various phases of degradation [10,
$11,25]$, are not uncommon in the resting B-cell. Their contents suggest that either secretory granules, parts of the cytoplasm, or both, are degraded yielding eventually tertiary lysosomes or residual bodies. The latter characteristically show a heterogenous content lacking cytochemical reactivity for acid hydrolases $[11,13,25]$.

The interaction of lysosomes with secretory granules has been described as crinophagy $[14,37]$ or granulolysis $[29,30,32]$ in endocrine cells under experimental or pathological conditions linked to the need for disposal of a sudden large excess of secretory products $[8,9,29,32,37]$. Its existence in resting B-cells indicates that granule disposal may occur also in a normal secretory cycle. Autophagy is characterized by the segregation of cytoplasmic areas that contain secretory granules and/or other organelles. In this process, the origin of the membranes and of the enzymes involved is still a matter of debate [2, $11,13]$. The occurrence of autophagic vacuoles cytochemically unreactive and their frequent association with small reactive lysosomes, suggest that in Bcells, non-lysosomal membranes first form a vacuole into which hydrolases are later introduced by the lytic bodies. By contrast, the significance of AcPase-positive secretory granules apparently not involved in a digestive process is still unresolved $[14,16,19,20$, $27,33,35,37,38,39,40]$ as is the occurrence of AS positive granules; in this latter case, images suggest that granules may acquire the enzyme by fusion with primary lysosomes.

In summary, our data show that morphological and cytochemical components of the lysosomal system are active in resting pancreatic cells and that digestive processes comprise both specific crinophagy 
or granulolysis and less specific autophagy. This suggests a probable turnover of granules and/or cytoplasmic components not necessarily linked to an active secretory state.

Acknowledgements. It is a pleasure to thank Dr. D. Brown, Prof. S. Haumont and Dr. J.-C. Henquin for critically reading the manuscript, Miss L. Vanderstraaten, Mrs. J. Vander Perre, Mrs. H. Claes and Mr. J. Goosens for technical assistance.

\section{References}

1. Amherdt, M., Rufener, C., Malaisse-Lagae, F.: Ultrastructural cytochemistry of islet cells. Diabetologia 11, 329 (1975)

2. Arstila, A. U., Trump, B. F.: Studies on cellular autophagocytosis. The formation of autophagic vacuoles in the liver after glucagon administration. Am. J. Pathol. 53, 687-733 (1968)

3. Barka, T., Anderson, P.J.: Histochemical methods for acid phosphatase using hexazonium pararosanilin as coupler. J. Histochem. Cytochem. 10, 741-753 (1962)

4. Bartók, I., Totović, V., Gedigk, P.: Ưber die Entstehung der peribiliären dichten Körper der Leberzellen. Untersuchungen in der präregeneratorischen Phase nach subtotaler Hepatektomie. Virchows Arch. [Pathol. Anat.] 343, 1-19 (1967)

5. Bommer, G., Schäfer, H.-J., Klöppel, G.: Morphologic effects of diazoxide and diphenylhydantoin on insulin secretion and biosynthesis in B-cells of mice. Virchows Arch. [Pathol. Anat.] 371, 227-241 (1976)

6. Brandes, D.: Observation on the apparent mode of formation of "pure" lysosomes. J. Ultrastruct. Res. 12, 63-80 (1965)

7. Cohn, Z.A., Fedorko, M.E.: The formation and fate of lysosomes. In: J. T. Dingle, H. B. Fell (eds.): Lysosomes in biology and pathology. Vol. 1, p. 43-63. Amsterdam: North-Holland Publ. 1969

8. Creutzfeldt, W., Creutzfeldt, C., Frerichs, H., Perings, E., Sickinger, K.: The morphological substrate of the inhibition of insulin secretion by diazoxide. Horm. Metab. Res. 1, 53-64 (1969)

9. Creutzfeldt, W., Frerichs, H., Creutzfeldt, C.: The stimulation and inhibition of insulin secretion in vivo and in vitro. In: J. Ostman, R. D. G. Milner (eds.): Diabetes. Proc. 6 Congr. Int. Diabetes Fed., p. 110-122. Amsterdam: Excerpta Medica 1969

10. Daems, W. T., Wisse, E., Brederoo, P.: Electron microscopy of the vacuolar apparatus. In: J.T. Dingle, H. B. Fell (eds.): Lysosomes in biology and pathology. Vol. 1, p. 64-112. Amsterdam: North-Holland Publ. 1969

11. De Duve, C., Wattiaux, R.: Functions of lysosomes. Annu. Rev. Physiol. 28, 435-492 (1966)

12. Dixon, J.S.: "Phagocytic" lysosomes in chromatolytic neurones. Nature 215, 657-658 (1967)

13. Ericsson, J. L.E.: Mechanism of cellular autophagy. In: J.T. Dingle, H. B. Fell (eds.): Lysosomes in biology and pathology. Vol. 2, p. 345-394. Amsterdam: North-Holland Publ. 1969

14. Farquhar, M.: Lysosomes function in regulating secretion: disposal of secretory granules in cells of the anterior pituitary gland. In: J. T. Dingle, H. B. Fell (eds.): Lysosomes̀ in biology and pathology. Vol. 2, p. 462-482. Amsterdam: North-Holland Publ. 1969

15. Forssmann, W. G., Orci, L.: Ultrastructure and secretory cycle of the gastrin-producing cell. Z. Zellforsch. 101, 419-432 (1969)
16. Garrett, J.R., Kidd, A.: Acid phosphatase and peroxidase in "resting" acinar cells of the major salivary glands of cats and their possible movement into secretory granules. Histochem. J. 8, 523-538 (1976)

17. Goldfischer, S.: The cytochemical demonstration of lysosomal arylsulfatase activity by light and electron microscopy. $J$. Histochem. Cytochem. 13, 520-523 (1965)

18. Gomori, G.: Histochemical methods for acid phosphatase. J. Histochem. Cytochem. 4, 453-461 (1956)

19. Holtzman, E., Dominitz, R.: Cytochemical studies of lysosomes, Golgi apparatus and endoplasmic reticulum in secretion and protein uptake by adrenal medulla cells of the rat. J. Histochem. Cytochem. 16, 320-336 (1968)

20. Kemmler, W., Peterson, J.D., Rubenstein, A.H., Steiner, D.F.: On the biosynthesis, intracellular transport and mechanism of conversion of proinsulin to insulin and C-peptide. Diabetes 21 (Suppl. 2), 572-583 (1971)

21. Lacy, P.E., Kostianovsky, M.: Method for the isolation of intact islets of Langerhans from the rat pancreas. Diabetes 16, 35-39 (1967)

22. Lazarus, S.S., Volk, B.W., Barden, H.: Localization of acid phosphatase activity and secretion mechanism in rabbit pancreatic B-cells. J. Histochem. Cytochem. 14, 233-246 (1966)

23. Luft, J.H.: Improvements in epoxy resin embedding methods. J. Biophys. Biochem. Cytol. 9, 409-414 (1961)

24. Melmed, R. N., Benitez, C. J., Holt, S. J.: Intermediate cells of the pancreas. III. Selective autophagy and destruction of $\beta$ granules in intermediate cells of the rat pancreas induced by alloxan and streptozotocin. J. Cell Sci. 13, 297-315 (1973)

25. Novikoff, A. B.: Lysosomes : a personal account. In: H.G. Hers, F. Van Hoof (eds.): Lysosomes and storage diseases, p. 1-41. New York and London: Academic Press 1973

26. Novikoff, P. M., Novikoff, A. B., Quintana, N., Hauw, J.-J.: Golgi apparatus, GERL, and lysosomes of neurons in rat dorsal root ganglia, studied by thick section and thin section cytochemistry. J. Cell Biol. 50, 859-886 (1971)

27. Novikoff, A. B., Yam, A., Novikoff, P. M.: Cytochemical study of secretory process in transplantable insulinoma of syrian golden hamster. Proc. Natl. Acad. Sci. USA 72, 4501-4505 (1975)

28. Orci, L.: A portrait of the pancreatic B-cell. Diabetologia 10, 163-187 (1974)

29. Orci, L., Junod, A., Pictet, R., Renold, A. E., Rouiller, C.: Granulolysis in A cells of endocrine pancreas in spontaneous and experimental diabetes in animals. J. Cell Biol. 38, 462-466 (1968)

30. Orci, L., Renold, A.E., Rouiller, C.: Intracellular " $\alpha$ granulolysis" in $\alpha$-cells of diabetic animals. In: S. Falkmer, Hellman, B., Täljedal, I. B. (eds.): The structure and metabolism of the pancreatic islets, p. 109-114. Oxford: Pergamon Press 1970

31. Orci, L., Stauffacher, W., Beaven, D., Lambert, A. E., Renold, A.E., Rouiller, C.: Ultrastructural events associated with the action of tolbutamide and glibenclamide on pancreatic B-cells in vivo and in vitro. Acta Diabetol. Lat. 6 (Suppl. 1), 271-374 (1969)

32. Orci, L., Stauffacher, W., Dulin, W. E., Renold, A. E., Rouiller, C.: Ultrastructural changes in A-cells exposed to diabetic hyperglycemia. Observations made on pancreas of chinese hamsters. Diabetologia 6, 199-206 (1970)

33. Orci, L., Stauffacher, W., Rufener, C., Lambert, A. E., Rouiller, C., Renold, A. E.: Acid phosphatase activity in secretory granules of pancreatic beta cells of normal rats. Diabetes $\mathbf{2 0}$, $385-388(1971)$

34. Palay, S. L.: The fine structure of secretory neurons in the preoptic nucleus of the goldfish (Carassius auratus). Anat. Rec. 138, 417-443 (1960) 
35. Smith, R. E.: Summary of discussion. Diabetes 21 (Suppl. 2), 581-583 (1972)

36. Smith, R.E., Farquhar, M.G.: Preparation of thick sections for cytochemistry and electron microscopy by a non-freezing technique. Nature 200, 691 (1963)

37. Smith, R. E., Farquhar, M. G.: Lysosome function in the regulation of the secretory process in cells of the anterior pituitary gland. J. Cell Biol. 31, 319-347 (1966)

38. Steiner, D. F., Kemmler, W., Clark, J. L., Oyer, P. E., Rubenstein, A. H.: The biosynthesis of insulin. In: D. F. Steiner, N. Freinkel (eds.): Handbook of physiology. Vol. 1, Sect. 7, p. 175-198. Washington, D. C.: American Physiological Society 1972

39. Wollman, S. H., Spicer, S. S., Burstone, M.S.: Localization of esterase and acid phosphatase in granules and colloid droplets in rat thyroid epithelium. J. Cell Biol. 21, 191-201 (1964)
40. Zühlke, H., Steiner, D. F., Lernmark, Å., Lipsey, C.: Carboxypeptidase $B$-like and trypsin-like activities in isolated rat pancreatic islets. In: Polypeptide hormones : molecular and cellular aspects. Ciba Foundation Symposium 41, 183-195. Amsterdam: Elsevier-Excerpta Medica North-Holland 1976

Received: February 9, 1977,

and in revised form: December 2, 1977

Dr. P. Meda

Department of Histology

University of Louvain

Faculty of Medicine

B-1200 Brussels

Belgium 